Portland State University

PDXScholar

6-16-2021

\title{
Trauma and Child Development: The Effects That Ice Detention Centers May Have On Our Children
}

Natalie A. DeWitt

Portland State University

Follow this and additional works at: https://pdxscholar.library.pdx.edu/honorstheses

Part of the Child Psychology Commons, and the Development Studies Commons Let us know how access to this document benefits you.

Recommended Citation

DeWitt, Natalie A., "Trauma and Child Development: The Effects That Ice Detention Centers May Have On Our Children" (2021). University Honors Theses. Paper 1021.

https://doi.org/10.15760/honors.1054

This Thesis is brought to you for free and open access. It has been accepted for inclusion in University Honors Theses by an authorized administrator of PDXScholar. Please contact us if we can make this document more accessible: pdxscholar@pdx.edu. 
Trauma and Child Development:

The Effects That ICE Detention Centers May Have on Our Children

$$
\text { by }
$$

Natalie A DeWitt

An undergraduate honors thesis submitted in partial fulfillment of the requirements for the degree of

Bachelor of Science

in

University Honors

and

Psychology and Mathematics for Middle School Teachers

Thesis Advisor

Joanna Bartlo

Portland State University

Spring, 2021 


\begin{abstract}
Many people immigrating to the United States across the Southern border are often caught and detained by U.S. Immigration and Customs Enforcement (ICE) officials and placed in detention centers. The conditions under which immigrants are held in are traumatizing. Families are often separated for long periods and some have never been reunited. Many detention cells lack clean water, adequate food, beds, warmth, or privacy. Numerous allegations of abuse or misconduct toward adults and children have been reported, including medical malpractice. Children are forced to endure these conditions and navigate the immigration bureaucracy without the support of their family or trusted adults. The trauma produced by these conditions can cause severe and lasting psychological and health effects to children, especially when not appropriately treated. These effects cause permanent damage to the developing brain, altering structures and chemical systems within the child's body and greatly increasing the risk of physical disease and mental illness in adult years. There needs to be an entire immigration system overhaul, with a focus on reducing and treating the trauma inflicted as well as reforming immigration policy to help migrants settle in safe environments.
\end{abstract}




\section{Introduction}

The United States is known for being a melting pot of immigrant families and descendants. Since Columbus "discovered" this land, waves of people have migrated to the West from countries around the world. More recently, increasing numbers of immigrants have migrated to the U.S. from Mexico, Central and South America in search of economic opportunity and freedom. These people are primarily crossing the southern border fleeing countries in which they face dangerous and often deadly conditions (Office of Refugee Resettlement, 2020). The journey to the U.S. proves to be perilous and terrifying, with many people kidnapped along the way and forced into sex and labor trafficking (Office of Refugee Resettlement, 2020). Immigrants used to be primarily men, but in the last twenty years there has been a large influx of families and unaccompanied children. Due to recent policy changes, the U.S. is now treating all immigrants and asylum seekers as criminals and detaining people in overcrowded centers (Najara, 2020). During the Trump administration, the U.S. began separating immigrant children from their families as well as holding them in detention facilities.

Currently the United States' Immigration and Customs Enforcement (ICE) have detention centers open around the country that are holding people caught while immigrating to the U.S. These detention centers have become notorious for the inhumane conditions in which they are holding people. This thesis will explore how trauma affects children and the likely effects ICE detention centers could have on the children. It will begin with an exploration of the conditions in which immigrants are being held followed by a review of the generalized effects of trauma on children. Ultimately this investigation will build the argument that because the conditions in which children are being held in ICE 
detention centers are traumatic, and because trauma negatively impacts a child's brain and health outcomes, ICE detention will likely cause irreparable damage to these children.

\section{ICE Detention Centers Background}

The U.S dramatically expanded the use of immigrant detention by enacting new legislation in 1996. The Antiterrorism and Effective Death Penalty Act (AEDPA) and the Illegal Immigrant Reform and Immigrant Responsibility Act (IIRIRA) "increased the scope of who could be subject to mandatory detention. The 1996 laws also rendered any non-U.S. citizen, including legal permanent residents, vulnerable to detention and deportation." (Detention Watch Network, 2021). Mandatory detention was originally created to prevent criminals from immigrating into the U.S., but expedited removal (also passed in 1996) allows low-level immigration officials to detain asylum seekers - including families - and automatically sentence them to mandatory detention until they are officially interviewed and determined to not be a threat (American Immigration Council, 2020). However, the U.S. government has systematically refused to release these asylum seekers after they have been legally cleared (Detention Watch Network, 2021). In 2003, the Immigration and Naturalization Service (INS) was replaced by the Department of Homeland Security and its agencies, including ICE, and the national security focus shifted to the removal of "criminal aliens" (Najera, 2020). There has been a massive shift from treating people as migrants to treating everyone, including families and children, as criminals (Najera, 2020). Furthermore, the immigration courts do not appoint attorneys, legal counsel, or translation services, and people (including children and even toddlers) are forced to represent themselves in an entirely English-speaking court, which is often a foreign language. 
Currently there are over 200 ICE detention centers in the U.S. Upon reaching the Southern border, all immigrants are sent through processing centers. These centers house immigrants who have been detained and are waiting for officials to determine their immigration status, either allowing them to enter the U.S. or face deportation - often with jail time first. Those held are all non-U.S. citizens and ICE detains both documented and undocumented immigrants including babies, pregnant women, and elderly people.

As of May 2021, "U.S. officials were holding more than 22,500 unaccompanied children who had recently crossed the border" (BBC, 2021). Many of the ICE detention centers are owned by private companies, who then charge the government per diem per person and have contractual quotas and minimums that determine how many people must be detained in each center at any given time (Lee, 2017). Thus, there are financial incentives to keep large numbers of immigrants in detention centers, and this has increased the number of people held. Detention centers are constantly finding ways to decrease the spending per person (including mass cuts to available health care) while increasing the number of detainees, which overall increases their profit and contributes significantly to the epidemic of mass incarceration. Local governments are paid to detain people, and these funds often fill the gaps in quickly shrinking budgets. What's more, the $287(\mathrm{~g})$ program allows local law enforcement to detain suspected illegal immigrants (McHugh, 2009). This program is a "force multiplier", or a way of massively expanding the number of officials with permission to detain immigrants - in 2008 one fifth of all illegal immigrants detained by ICE were captured by local officials. In 2019, 510,854 people were detained in 215 facilities, $81 \%$ of which were owned by private corporations (Detention Watch Network, 2021). 
Once detained, these immigrants face cruel and inhumane conditions. They are sorted and held by age and gender, resulting in the separation of siblings, toddlers from caregivers, and couples who traveled together (Linton, 2018). Following this, most immigrants are sent to detention centers to await the decision on their immigration status. Children are routinely separated from their parents, where they are either held separately in jails or placed in the foster care system until a court date is set. Their parents (who are held in detention facilities) are penalized for not attending hearings in family court, which are often states away from where they are being detained, and parental rights are terminated for not meeting court-ordered requirements to regain custody. According to the Washington Post, the U.S. "lost track" of 1,475 immigrant children in 2018 that were in their custody (Wang, 2019). Where did these children go, and what has happened to them while in the "care" of the U.S. government? Furthermore, the U.S. has not kept detailed records of the children who are separated from their families and has no way of reuniting them.

Because many immigrants are from Spanish speaking countries, the conditions in which people are being held are colloquially referred to by detainees as "perreras" [dog cages] and "hieleras" [ice boxes] due to their structure and freezing temperatures (Levinson \& Cooke, 2018). Photos of children and adults packed into cages and sleeping on the floor with thin reflective blankets have swept the nation. The conditions are clearly filthy and overcrowded, and with the onset of the COVID-19 pandemic, concerns around sanitation and health increased (see Figure 1.). A legal team interviewed 60 children that were held in Texas who described inadequate water, food, and medical support as well as neglect and a lack of sanitation. A visiting doctor described the cages as being extremely 
cold and having lights on 24 hours a day. No beds or blankets are provided, and only occasionally are thin foil blankets distributed. Members of congress who visited a facility in Texas were told by detained women that they were instructed to "drink from toilet bowls" due to a lack of running water (American Oversight, 2021). Numerous detainees have reported receiving small amounts of food and are sometimes given only one meal a day. Immigrants frequently do not have access to basic hygiene products such as soap and lack privacy for using the restroom and shower. People are held in the cells 24 hours a day and have no source of entertainment, stimulation, or ability to exercise. Children are not provided any education and are not given stimulating materials such as books or toys. Since 2003, over 214 people have died in these facilities (Detention Watch Network, 2021). Conditions in these centers violate the Geneva convention; the U.S. treats immigrants and asylum seekers worse than legally required to treat prisoners of war (Sukin, 2019).

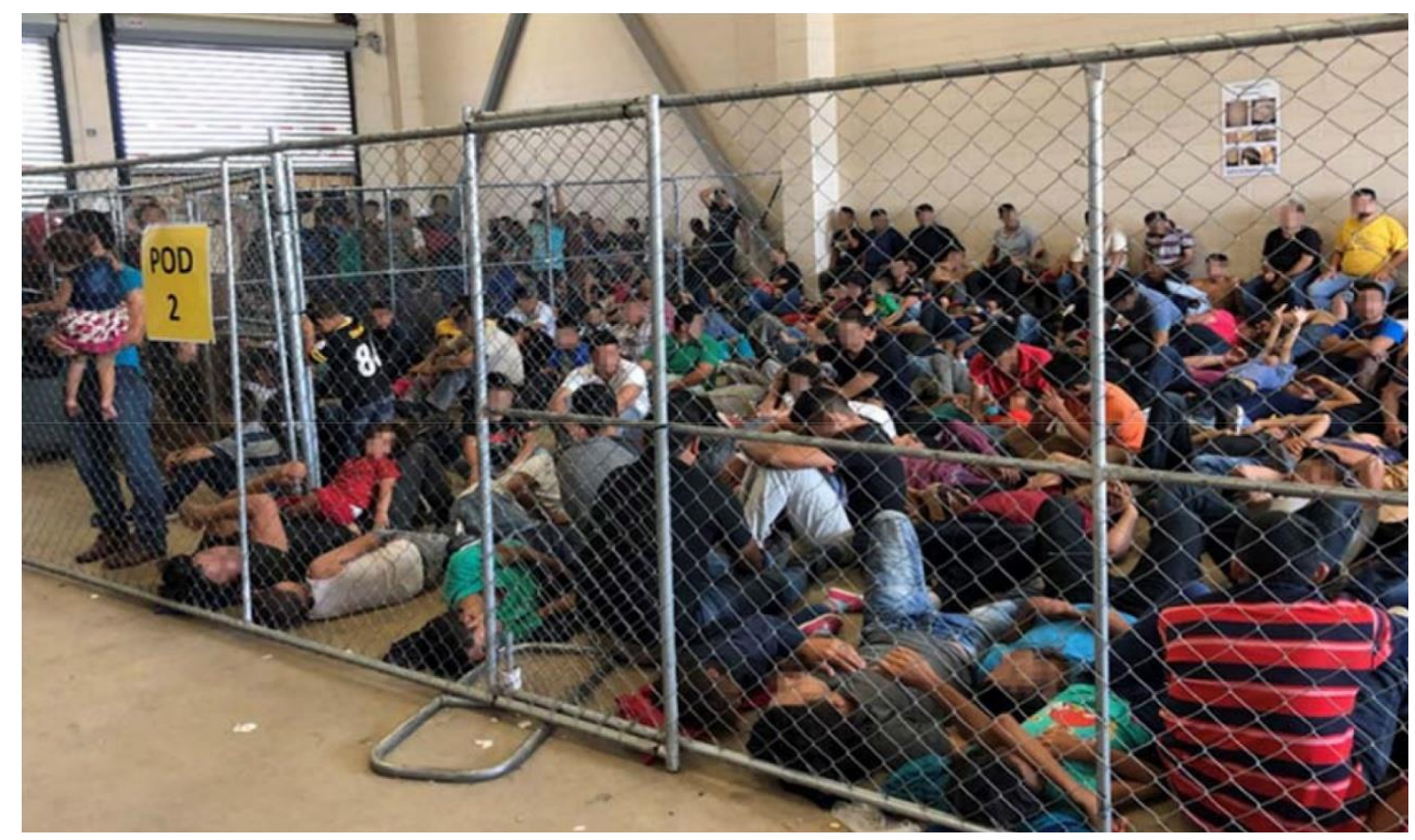

Figure 1. Immigrants in a facility are overcrowded in the "holding" areas (Gamboa, 2019). 
Trauma Experienced While in Detention Centers: neglect, sexual abuse, and medical mistreatment

In 2019, 16-year-old Carlos Gregorio Hernandez Vasquez was found dead in a cell by another teen. Video footage of the cell shows the teen weak and unable to stand, eventually collapsing on the floor of his small, concrete cell. This footage directly contradicts the official report from the Customs and Border Protections which states that Carlos was found dead by staff members during a welfare check (Gamboa, 2019). According to NBC he had been diagnosed with influenza the day before and a nurse practitioner recommended he be checked frequently, and if symptoms worsened, taken to a hospital (Silva, 2019). He was instead transferred from an over-crowded processing center to a Border Patrol station. He had been at the processing center for 8 days although law requires minors to be transferred to the custody of the Department of Homeland Security (DHS) within 72 hours. Carlos' family told Telemundo that he went to the U.S. in an attempt to help his 8 siblings at home, most of all his brother who had special needs. Carlos was the seventh immigrant child to die in custody that year (Acevedo, 2019).

In 2019 Congressman Ted Deutch made public records from the Department of Health and Human Services which stated that the Office of Refugee Resettlement (who care for under-age immigrants) received over 4,500 allegations of sexual abuse, around 1,300 of which were serious enough to involve the FBI. A large portion of the allegations reported abuse coming from other detainees, indicating a lack of surveillance and that the children are held in unsafe conditions. Most of the allegations involving staff centered around "youth-care workers who escort the children everywhere they go. The complaints range 
from inappropriate romantic relationships between children and adults, to touching genitals, to watching children shower," (Gonzales, 2019).

This "toxic stress, or prolonged, serious stress in the absence of buffering support, can have immediate devastating mental health effects..." (Linton, 2018). Furthermore, it also disrupts normal brain development and has strong associations with both short- and long-term health effects (Garner et al., 2012). Legally, children can be held in detention centers for a maximum of 72 hours, but many children are held for 10 days or longer before they are shuffled into the U.S. foster care system (Ordoñez, 2021).

Numerous cases of abuse to immigrants have been documented. Women report being bribed for "good behavior" and sexual affection in exchange for soap and other basic needs (Kriel, 2021). In 2020 the Texas Tribune reported that ICE guards were "systematically" sexually assaulting women in areas that were not visible to surveillance cameras (Kriel, 2021). An ICE spokesperson announced that ICE has "zero tolerance for any form of sexual abuse or assault against individuals in the agency's custody and takes very seriously all allegations of employee misconduct..." ICE then deported a key witness (Kriel, 2021). Another woman came forward about an attack where her and two other detainees were isolated, beaten, raped, and then bussed back to Mexico where one of them later found out she was pregnant (Kriel, 2021). In 2020 Dawn Wooten, a nurse who worked at an immigrant detention center in Georgia, filed a whistleblower complaint alleging "a lack of medical care and unsafe work practices that facilitated the spread of COVID-19" as well as "questionable hysterectomies" (Triesman, 2020). There are many documented instances of women who received medically unnecessary gynecological procedures including hysterectomies resulting in sterilization (Dickerson et al., 2020). 
Furthermore, a firsthand account from medical personnel gives us a glimpse into the absolute lack of rights detainees have. An unconscious young adult was brought into the emergency department by federal agents. This individual was unresponsive, shackled to the gurney, and placed on mechanical ventilation. When medical staff requested the handcuffs be removed for medical reasons, federal agents refused. The individual began to exhibit signs of a seizure and nursing prepared to administer an antiepileptic agent. However, they were prevented by the agents who stated they did not have permission to administer any medication at all until a forensic phlebotomist was able to collect a blood sample. The medical staff protested, and an agent replied, "This is not a patient, this is property of the State". It was made clear that the warden would make all medical decisions for this person; it was decided that they should be removed from life support and the individual died (Jenkins et al., 2020). From the numerous situations previously discussed it becomes apparent that immigrants are forced into are abusive and inhumane situations.

These are the stories that have been published about adults which leads to concerns about what more is happening to children. What is known is that at least seven children died in immigration custody between 2018 and 2019 (Acevedo, 2019). 7-year-old Jakelin Caal Maquin was taken on a 90-mile bus ride after her father told officials "she was vomiting and feeling ill..." - she then died of a "rapidly progressive infection' that shut down her vital organs" according to the official ICE report (Acevedo, 2019). 1-year-old Mariee Juarez died immediately after being released from ICE custody due to a respiratory illness she developed while detained; 2-year-old Wilmer Josué Ramírez Vásquez died in detention after developing pneumonia; Felipe Gómez Alonzo, 8, died from the flu on Christmas eve while in custody; 10-year-old Darlyn Valle died after a surgical procedure at 
an Arizona facility that left her in a coma; Juan de León Gutiérrez, 16, died of "health complications" while at a Texas detention facility after officials "noticed he was sick" (Acevedo, 2019). The conditions in which children are held in U.S. government detention centers are resulting in serious illness and death, as well as exposing the detainees to neglect, physical and sexual violence.

\section{Effects of Trauma on Children}

As children learn, grow, and explore the world around them there are various factors that influence their development and conceptualization of the world. Trauma can affect anybody, regardless of age, but it can be particularly damaging to a child and their developing brain and has even been linked to an increase in health risks and early death (Briggs et al., 2021). Trauma can be defined as a deeply distressing or disturbing experience, or an event in which there is an actual or perceived threat. This includes physical, sexual and emotional abuse, neglect, witnessing violence or aggression (domestic, relationship, and/or community), witnessing or taking part in drug use, witnessing death, abduction, war, and experiencing natural disasters (Legg, 2020). Generally, trauma encapsulates experiences in which an individual endures copious amounts of stress and if they are unable to cope in healthy ways, trauma will leave lasting effects on the person.

According to the National Survey of Children's Exposure to Violence, prevalence of childhood physical assault was $17-70 \%$ in the U.S., with $8-10 \%$ of youths experiencing at least one sexual assault and $25 \%$ of youths experiencing a natural disaster (Abraham et al., 2021). It is difficult to know the full extent of childhood trauma due to the nature of these events - abusers are often secretive and threaten those they abuse; children may be trying 
to protect those that they love, or live in fear that others will be harmed if they tell someone what is happening; nationally there is inadequate surveillance.

Trauma is often quantified using a checklist called Adverse Childhood Experiences (ACE) and the number of questions someone answers "yes" to makes up their ACE score. There are 10 questions total, and a score of 4 or higher typically signals high and intense levels of trauma. The questions assess verbal, physical, sexual, and emotional abuse, neglect, drug and alcohol exposure, mental illness exposure, parental divorce and parental incarceration. Numerous studies have linked high ACE scores with adverse health effects (Briggs et al., 2021). Since the development of the ACE score, numerous studies have shown associations between scores and health outcomes. It has repeatedly been found that higher scores result in higher levels of addiction, chronic disease, post-traumatic stress disorder, and depression (Chang et al., 2019) They are also related to higher suicide rates and heart disease, which lead to premature death (Merrick et al., 2017).

A study that explored ACE scores and the results of different pairings of experiences (answering questions like: does sexual abuse result in the same health outcomes as experiencing a natural disaster?) found that sexual abuse resulted in the most profound effects on the individual, followed by physical abuse and neglect (Briggs et al., 2021). Children held in U.S. detention centers experience all three. A 2006 study examined the differences in college women who had been repeatedly sexually abused as children against college women who experienced no abuse. Those who experienced this abuse showed an increased response latency variability as well as a lower inhibitory capacity. Additionally, a strong association was found between duration of abuse and memory impairment. Their 
math Scholastic Aptitude Test (SAT) scores were significantly lower as well. The researchers conclude "Childhood sexual abuse appears to be associated with a constellation of neuropsychological deficiencies even in a group of relatively healthy women," (Navata et al., 2006).

"Research has found that trauma exposure is a key element in child development, psychopathology, and functioning," (Saunders \& Adams, 2014). People who experience trauma in childhood are significantly more likely to develop anxiety and mood disorders (Abraham et al., 2021). All of these issues can be caused by impairment to the developing brain and adverse childhood experiences.

Trauma often results in post-traumatic stress disorder (PTSD). PTSD is characterized by symptoms such as anxiety, hypervigilance, depression, substance abuse, impulsivity, avoidance, disrupted sleep, a change in normal habits (such as repeatedly locking doors and windows), flashbacks, intrusive thoughts, and dissociation. Individuals experiencing PTSD have survived extreme circumstances and have adapted to their experiences with survival mechanisms which are not typically utilized by those who are mentally well. When someone is in crisis, their body automatically experiences an acute stress response, commonly known as fight, flight, or freeze. Prolonged exposure to this stress causes biochemical alterations to an individual's neurotransmitters which allows the body to adapt to the stress response. Abnormal regulation of catecholamine, serotonin, and cortisol (all of which are found in brain circuits that regulate stress and fear responses) become necessary for an individual experiencing extreme conditions as they remain hyperaware and in survival mode (Sherin \& Nemeroff, 2011). 
Numerous studies have found that people diagnosed with PTSD are more likely to experience physical health problems such as arthritis, heart disease, respiratory system related issues, digestive problems, reproductive system related issues, diabetes, and pain (Tull, 2020). When a person is responding to acute stress, their body focuses on the processes needed to survive. The heart beats faster, sending oxygenated blood to the muscles in preparation to fight and flee. The internal temperature will drop due to an expectation of physical exertion. The brain works in a heightened state and focuses on the perceived threat. When the body is in this state for prolonged periods, typical functions (such as digestion and the immune response) are suppressed. When the body cannot carry out all of its normal functions it becomes difficult to remain healthy which is why PTSD is related to so many health disorders. When an individual is constantly in this heightened state, it is difficult to engage in healthy behaviors (exercise, sufficient sleep, eating balanced meals) which intensifies the damage done to the body (Pietrzak et al., 2012).

PTSD is particularly damaging to children, whose brains are developing. Research has shown that children with PTSD and heightened cortisol levels are likely to develop a smaller than normal hippocampus. This is the brain structure that processes memories and emotion, and the prolonged stress damages this structure. "In a vicious cycle, a reduction in hippocampal size can make it more difficult for a child to process and deal with traumatic events, which in turn may raise both stress and cortisol levels that cause even more damage," (Carrion, 2007). When children experience prolonged trauma, their brains develop while in this stress response mode, leading them to be tuned into constant danger. This priming negatively impacts them in numerous ways: they have difficulty forming healthy attachments with others, experience impaired sensorimotor development, have 
difficulty with emotion regulation, a decrease in cognitive abilities, a lack of consistent positive self-concept, and low behavioral control (Peterson, 2018). For some time, the psychological community has been aware through extensive research of the damaging effects PTSD has on children and it is clear that detained children are experiencing bodyand mind-altering conditions.

PTSD is not incurable. Trauma focused psychotherapies have proven to be very effective in treating PTSD with practices including cognitive processing therapy, prolonged exposure, and eye movement desensitization and reprocessing (Veterans Affairs, 2018). However, access to treatment can prove difficult. Services are very expensive and, without adequate insurance, unattainable for most people. In the U.S., it is very difficult to find therapists that are people of color or speak languages other than English. Due to financial barriers, privacy concerns, and social stigma research has found that immigrants are less likely to seek help than people born in the U.S. (Hodges, 2020). Even after they enter the U.S., most immigrants will not receive the support they need.

\section{Linking It Together}

While in the U.S. government's facilities children are continually traumatized, held in cage-like facilities with inhumane conditions and subjected to abuse by those who are supposed to care for them. The children are torn from their parents and siblings and rarely reunited. Within the detention centers there is a lack of basic human needs including adequate food, clean water, hygiene products, and privacy. Temperatures are cold and holding cells are overcrowded. Lights are on 24 hours a day. Detainees are not provided beds nor blankets (save the thin foil sheets occasionally distributed) and sleep on concrete 
floors. They are in the cells all hours of the day with no source of exercise, entertainment, or mental stimulation. Additionally, the health care provided is limited and inadequate. There are numerous reports of unnecessary gynecological procedures. Many detainees have reported extensive physical and sexual abuse. Children receive no education and are not provided with learning tools such as books and toys. Abusers are secretive and children have difficulty advocating for themselves, indicating that the actual extent of abuse is not known. This trauma does irreparable harm to the developing human brain and has been shown to have severe short- and long-term health effects. A child's brain is forced to develop under these extreme conditions resulting in abnormalities in structures, neurotransmitters, and responses. This damage will follow them for the rest of their lives and will likely manifest itself as PTSD as well as physical health issues. The treatment these children are receiving is harmful, unethical, and abusive. The ways that this trauma is altering their brains and development is permanent.

\section{Implications}

Immigrants are being held in abusive and inhumane conditions for extended periods of time. Those held are both documented and undocumented people, those who have just arrived to the United States and those who have lived there for most of their lives, elderly persons, pregnant women, children, and infants. Adults in these jails are subjected to abuse, neglect, and illegal treatment. Children are subjected to all of that while their brains are still developing. While in these detention centers, the children being held would receive an ACE score of 7-10 indicating extremely severe levels of trauma. Exposure to trauma, especially toxic stress, is particularly detrimental to children and can severely 
inhibit their ability to develop normally. With very high ACE scores, these children are likely to experience effects from their trauma for the rest of their lives, with many of them battling substance abuse, mental health issues, and heart disease. Even after being released from detainment children are likely to have PTSD and are often never reunited with their families, instead adopted out by DHS. Something must change.

It is abundantly clear that the United States needs a massive overhaul of its immigration system. There should be video surveillance of all parts of all detention and processing centers, running at all times and reviewed by separate government agencies. An intentional vetting of guards and agents is needed, with severe punishments for those engaging in abusive and negligent behaviors. There needs to be an outside entity that is responsible for processing, accepting, and working through all allegations and abuse reports, with the resources to appropriately investigate the claims and support the victims throughout the process. Immigrants should be informed of their rights and receive at least basic legal counsel throughout the immigration process, with provided translators when necessary. There needs to be sufficient tracking and documentation of all immigrants to keep families together and not lose track of children and their parents. We must prioritize reunification and reparations, helping those who have been harmed in such intense ways by the U.S. system, and finally rejoining families that have been separated for so long. Therapeutic services should be publicly available, in multiple languages, for those who wish to receive treatment. There needs to be a revamp of all facilities and their conditions, including adequate heat, water, space, food, stimulation, and medical services. After all, these are basic human needs and everyone deserves to have access to them, especially those being held against their will. The U.S. clearly needs a different processing system - 
most people would agree that children should not be held in jail systems and it is unjust to detain people who represent no threat and have done nothing more than flee horrific conditions. The processing needs to be accessible, with translators and counselors, and the path to citizenship should be at a fair price and attainable within a reasonable time frame. We are all Americans after all, and whether you come from the northern or southern end of the continent should not matter. Those living in the U.S. are nearly all descendants of immigrants, and we should understand their plight. After all, we are all human. 


\section{References}

Abraham, E. H., Antl, S. M., \& McAuley, T. (2021). Trauma exposure and mental health in a community sample of children and youth. Psychological Trauma: Theory, Research, Practice, and Policy, doi:http://dx.doi.org.proxy.lib.pdx.edu/10.1037/tra0001035

Acevedo, N. (2019, May 30). Why are migrant children dying in U.S. custody? NBCNews.com. https://www.nbcnews.com/news/latino/why-are-migrant-children-dying-u-scustody-n1010316.

American Immigration Council. A Primer on Expedited Removal. American Immigration Council. (2020, December 16). https://www.americanimmigrationcouncil.org/research/primer-expeditedremoval.

American Oversight. Conditions in Migrant Detention Centers. American Oversight. (2021, January 20). https://www.americanoversight.org/investigation/conditions-inmigrant-detention-centers.

BBC. Child migrants: Massive drop in children held by border officials. (2021, May 05). Retrieved from https://www.bbc.com/news/world-us-canada-56405009

Briggs, E. C., Amaya-Jackson, L., Putnam, K. T., \& Putnam, F. W. (2021). All adverse childhood experiences are not equal: The contribution of synergy to adverse childhood experience scores. American Psychologist, 76(2), 243-252. https://doiorg.proxy.lib.pdx.edu/10.1037/amp0000768 (Briggs et al., 2021)

Carrion, V. (2007, March 4). Severe PTSD damages children's brains, Stanford/Packard study shows. Retrieved from https://med.stanford.edu/news/allnews/2007/03/severe-ptsd-damages-childrens-brains-stanfordpackard-study- 
shows.html\#: :text=Severe PTSD damages children's brains, Stanford/Packard study shows,-Mar 4 2007\&text=STANFORD, Calif,,and Lucile Packard Children's Hospital.

Cederlöf, M., Östberg, P., Pettersson, E., Anckarsäter, H., Gumpert, C., Lundström, S., \& Lichtenstein, P. (2014, June 25). Language and mathematical problems as precursors of psychotic-like experiences and juvenile mania symptoms. KI Open Archive Home. https://openarchive.ki.se/xmlui/handle/10616/42107.

Chang, X., Jiang, X., Mkandarwire, T., \& Shen, M. (2019). Associations between adverse childhood experiences and health outcomes in adults aged 18-59 years. PLOS ONE. https://journals.plos.org/plosone/article/metrics?id=10.1371\%2Fjournal.pone.021 1850\#citedHeader.

Conditions in Migrant Detention Centers. American Oversight. (2021, January 20). https://www.americanoversight.org/investigation/conditions-in-migrantdetention-

Córdova, F. M. (2017, June). Childhood Cut Short: Sexual and Gender-based Violence Against Central American Migrant and Refugee Children. Kids in Need of Defense (KIND) \& Human Rights Center https://supportkind.org/wpcontent/uploads/2017/06/Childhood-Cut-Short-KIND-SGBV-Report_June2017.pdf. centers.

Detention Watch Network. (2021, April 23). Immigration Detention 101. Detention Watch Network. https://www.detentionwatchnetwork.org/issues/detention-101.

Dickerson, C., Wessler, S. F., \& Jordan, M. (2020, September 29). Immigrants Say They Were Pressured Into Unneeded Surgeries. The New York Times. 
https://www.nytimes.com/2020/09/29/us/ice-hysterectomies-surgeriesgeorgia.html.

Gamboa, S. (2019, December 7). Video contradicts border agency's account of death of ill migrant teen in its custody. NBCNews.com. https://www.nbcnews.com/news/latino/video-contradicts-border-agency-saccount-death-ill-migrant-teen-n1097006.

Garner, A. S., Shonkoff, J. P., Siegel, B. S., Dobbins, M. I., Earls, M. F., McGuinn, L., Wood, D. L. (2012, January 1). Early Childhood Adversity, Toxic Stress, and the Role of the Pediatrician: Translating Developmental Science Into Lifelong Health. American Academy of Pediatrics. https://pediatrics.aappublications.org/content/129/1/e224.short.

Gonzales, R. (2019, February 27). Sexual Assault Of Detained Migrant Children Reported In The Thousands Since 2015. NPR. https://www.npr.org/2019/02/26/698397631/sexual-assault-of-detainedmigrant-children-reported-in-the-thousands-since-2015.

Human Rights First. (2017, July). Dangerous Territory Mexico Still Not Safe for Refugees. Human Rights First. https://www.humanrightsfirst.org/sites/default/files/HRFMexico-Asylum-System-rep.pdf.

Hodges, L. (2020, January 23). Going To Therapy Can Be Hard, Especially For Immigrants Here's How To Start. Retrieved from https://www.npr.org/2020/01/23/799004218/going-to-therapy-can-be-hardespecially-for-immigrants-heres-how-to-start\#: :text= 
Jenkins, D, Holmes, D, Burton, C, Murray, SJ. (2020, June 19). 'This Is Not a Patient, This Is Property of the State': Nursing, ethics, and the immigrant detention apparatus. Nurse Inq. 27:e12358. https://doi-org.proxy.lib.pdx.edu/10.1111/nin.12358

Kriel, L. (2020, August 14). ICE guards "systematically" sexually assault detainees in an El Paso detention center, lawyers say. The Texas Tribune. https://www.texastribune.org/2020/08/14/texas-immigrant-detention-ice-elpaso-sexual-abuse/.

Lee, E. Y. H. (2017, November 29). Report on immigration detention centers raises questions of 'perverse financial incentive'. ThinkProgress. https://archive.thinkprogress.org/immigration-detention-facilities-dwn-ccrlawsuit-dd3394b113dc/.

Legg, T. J. (2020, June 3). What is trauma? Retrieved from https://www.medicalnewstoday.com/articles/trauma

Levinson, R., \& Cooke, K. (2018, July 18). Migrants in U.S. custody describe life in 'ice boxes' and 'dog pounds'. Retrieved from https://www.reuters.com/article/us-usaimmigration-conditions/migrants-in-u-s-custody-describe-life-in-ice-boxes-anddog-pounds-idUSKBN1K82X1

Linton, J. M. (2018, September). Unaccompanied children seeking safe haven: Providing care and supporting well-being of a vulnerable population. ScienceDirect. https://wwwsciencedirect-com.proxy.lib.pdx.edu/science/article/pii/S0190740917310393.

McHugh, P. (2009, October 26). The 287(g) Program. CIS.org. https://cis.org/Report/287gProgram?gclid=CjwKCAjwgOGCBhAlEiwA7FUXkq3woIADZV1aAPjBHA8ILnHcp8rNc DvtKKg98bOItDTny4hCDixHvBoCpl0QAvD_BwE. 
Merrick, M. T., Ports, K. A., Ford, D. C., Afifi, T. O., Gershoff, E. T., \& Grogan-Kaylor, A. (2017, April 15). Unpacking the impact of adverse childhood experiences on adult mental health. Child Abuse \& Neglect. https://www.sciencedirect.com/science/article/abs/pii/S0145213417301084?cas a_token=cBtD_uAk_h8AAAAA\%3AIj1bzkaY4c5Ut-yfJYGmXihR5dKm5jWUwRUUx3fznjgEIAPMWQ9omImoV5-V7DPR1QIr5ZPgw.

Najera, J. (2020, October 01). Op-Ed: Why abuse and neglect of immigrants proliferate in ICE detention. Retrieved from https://www.latimes.com/opinion/story/2020-1001/immigrants-detention-ice-abuse-hysterectomies

Navalta, C. P., Polcari, A., Webster, D. M., Boghossian, A., Teicher, M. H., Andersen, S. L. (2006, February 1). Effects of Childhood Sexual Abuse on Neuropsychological and Cognitive Function in College Women. The Journal of Neuropsychiatry and Clinical Neurosciences. https://neuro.psychiatryonline.org/doi/full/10.1176/jnp.18.1.45.

Office of Refugee Resettlement. (2020). Facts and Data. U.S. Department of Human \& Health Services. https://www.acf.hhs.gov/orr/about/ucs/facts-and-data\#countryoforigin. Ordoñez, F. (2021, March 19). Hundreds Of Migrant Children Held In Border Detention For More Than 10 Days. Retrieved from https://www.npr.org/2021/03/18/979014713/hundreds-of-migrant-childrenheld-in-border-detention-for-more-than-10-days

Peterson, S. (2018, June 11). Effects. Retrieved from https://www.nctsn.org/what-is-childtrauma/trauma-types/complex-trauma/effects

Pietrzak, R. H., Goldstein, R. B., Southwick, S. M., \& Grant, B. F. (2012). Physical health conditions associated with posttraumatic stress disorder in U.S. older adults: results 
from wave 2 of the National Epidemiologic Survey on Alcohol and Related Conditions. Journal of the American Geriatrics Society, 60(2), 296-303. https://doi.org/10.1111/j.1532-5415.2011.03788.x

Saunders, B. E., \& Adams, Z. W. (2014). Epidemiology of traumatic experiences in childhood. Child and adolescent psychiatric clinics of North America, 23(2), 167-vii. https://doi.org/10.1016/j.chc.2013.12.003

Sherin, J. E., \& Nemeroff, C. B. (2011). Post-traumatic stress disorder: the neurobiological impact of psychological trauma. Dialogues in clinical neuroscience, 13(3), 263-278. https://doi.org/10.31887/DCNS.2011.13.2/jsherin

Silva, D. (2019, May 22). Migrant boy who died in U.S. custody wanted to help brother with special needs, family says. NBCNews.com. https://www.nbcnews.com/news/latino/migrant-boy-who-died-u-s-custodywanted-help-brother-n1008826.

Sukin, L. (2019, July 26). The United States Treats Migrants Worse Than Prisoners of War. Retrieved from https://foreignpolicy.com/2019/07/26/the-united-states-treatsmigrants-worse-than-prisoners-of-war/

Trauma Treatment Program: Mental Health Treatment: Nashville TN. Integrative Life Center. (2021, January 25). https://integrativelifecenter.com/therapy/traumatreatment/.

Treisman, R. (2020, September 16). Whistleblower Alleges 'Medical Neglect,' Questionable Hysterectomies Of ICE Detainees. NPR. https://www.npr.org/2020/09/16/913398383/whistleblower-alleges-medicalneglect-questionable-hysterectomies-of-ice-detaine. 
Tull, M. (2020, January 23). How PTSD Relates to Physical Health Issues. Retrieved from https://www.verywellmind.com/ptsd-and-physical-health-2797522

U.S. Department of Human \& Health Services. (2020). Facts and Data. The Administration for Children and Families. https://www.acf.hhs.gov/orr/about/ucs/facts-anddata\#countryoforigin.

Veterans Affairs. (2018, August 08). Retrieved from https://www.ptsd.va.gov/understand_tx/tx_basics.asp

Wang, A. B. (2019, April 28). The U.S. lost track of 1,475 immigrant children last year. Here's why people are outraged now. The Washington Post. https://www.washingtonpost.com/news/post-nation/wp/2018/05/27/the-u-slost-track-of-1500-immigrant-children-last-year-heres-why-people-are-outragednow/. 